мист-ва: 17.00.03 «Музичне мистецтво»/ О. В. Срошенко. - Харків, 2008. - 19 с. 3. Маруфенко О. В. Формування вокально-слухових навичок майбутнього вчителя музики: дис. ... канд. пед. наук: спец. 13.00.02 «Теорія та методика навчання музики і музичного виховання»/ Олена Вікторівна Маруфенко. - К., 2006. - 265 с. 4. Михайлець В. В. Вокальна основа хорового мистецтва: історичний та теоретичний аспекти: автореф. дисертації на здобуття наукового ступеню кандидата мист-ва: 17.00 .03 «Музичне мистецтво»/ В. В. Михайлець. - Одеса., 2004. - 18 с. 5. Панченко Г. П. Методика розвитку творчих здібностей майбутнього вчителя музики в процесі вокальної підготовки: автореф. дис. на здобуття наукового ступеня канд. пед. наук: спец. 13.00.02 «Теорія та методика навчання музики і музичного виховання» / Г. П. Панченко. - К., 2008. - 24 с. 6. Чжан Ї. Вокально-педагогічна творчість як передумова виконавської діяльності співака: автореф. дис. на здобуття наукового ступеня канд. мистецтвознавства: 17.00 .03 «Музичне мистецтво»/ Ї. Чжан. - Одеса, 2006. - 18 с. 7. Чуньпен Лі. Методика формування вокальної компетентності майбутніх учителів музики: автореф. дис. на здобуття наукового ступеня канд. пед. наук: спец. 13.00.02 «Теорія та методика навчання музики i музичного виховання» / Лі Чуньпен. - К., 2013. - 20 с.

УДК 371.15

Ірина Пальикова

\title{
ПІДГОТОВКА ВЧИТЕЛЯ В КОНТЕКСТІ СУЧАСНОЇ ГУМАНІСТИЧНОЇ ОСВІТНЬОЇ ПАРАДИГМИ
}

Пальшкова І. О. Підготовка вчителя в контексті сучасної гуманістичної освітньої парадигми.

Гуманна спрямованість змісту освіти у вищий школі реалізується через комплексний розвиток особистості засобами педагогічних дисциплін, забезпечується системою педагогічних умов, з-поміж яких: створення ситуацій успіху в пізнавальній діяльності; реалізація диференційованого підходу до побудови змісту навчальної роботи студентів; організація групових форм пізнавальної діяльності на основі співтворчості та співпраці у системі «викладач - студент»; залучення учнів до участі в пізнавальних іграх, розроблених на основі актуального матеріалу.

Ключові слова: гуманізація, підготовка вчителя, система «викладач - студент», гуманістична освітня парадигма, пізнавальні ігри.

Пальшкова И. А. Подготовка учителя в контексте современной гуманистической образовательной парадигмы.

Гуманная направленность содержания образования в высший школе реализуется через комплексное развитие личности средствами педагогических дисциплин, обеспечивается системой педагогических условий, среди которых: создание ситуаций успеха в познавательной деятельности; реализация дифференцированного подхода к построению содержания учебной работы студентов; организация групповых форм познавательной деятельности на основе сотворчества и сотрудничества в системе «преподаватель - студент»; включение учеников в познавательные игры, разработанных на основе актуального материала.

Ключевые слова: гуманизация, подготовка учителя, система «преподаватель студент», гуманистическая образовательная парадигма, познавательные игры. 
Palshkova I. O. Teacher education in the context of current humanistic educational paradigm.

The human orientation of educational content at higher schools is implemented through complex personality development with the help of pedagogical disciplines, provided with the system of pedagogic conditions among which the following should be mentioned: creating situations of achieving success in cognitive activity; implementing the differentiated approach to forming the content of students' training activity; organizing group forms of cognitive activity based on co-authorship and co-operation in the system "teacher-to-student"; including pupils in educational games developed on timely material.

Key words: humanization, teacher education, system "teacher-to-student", humanistic educational paradigm, educational games.

У період державно-політичного й соціально-економічного реформування в Україні виникла необхідність радикальних змін структури і змісту вищої педагогічної освіти на засадах реалізації принципів фундаменталізації, гуманізації, гуманітаризації й диференціації. Важливим результатом у цьому напряму стала реалізація у вищій школі багаторівневої системи підготовки спеціаліста, орієнтована на якісно новий порядок залучення випускників педагогічних ВНЗ до трудової діяльністі. При цьому розширені можливості одержання педагогічних спеціальностей шляхом уведення екстернату й дистанційного навчання.

Одним із шляхів подолання ситуації, що склалася в системі підготовки майбутнього вчителя, $\epsilon$ аналіз моделей особистості вчителя. Ми не будемо охоплювати всіх наявних підходів до аналізу цієї проблеми, а лише виокремимо ті теорії, які передбачають використання діяльнісного підходу у формуванні особистості вчителя. Особистість учителя будемо оцінювати 3 позиції ціннісної інтеграції інтегративного вияву особистості і визначимо спрямованість процесу становлення особистості вчителя як єдиного цілого. Адже тільки ціле визначає його частини, функціонування особистості є виявом єдиного, що може бути представлено як система, що складається 3 функціонуючих підсистем. При цьому наша позиція визначається загальною теорією систем, яка розглядає процеси в живих системах як процеси певної спрямованості - ціле визначає частини, а не частини ціле.

Подоланню формалізму в засвоєнні знань сприяє побудова навчального процесу на гуманній основі. Це питання всебічно досліджується у працях І. Беха, В. Бондаря, С. Гончаренка, І. Зязюна, Л. Кондрашової, В. Кременя, Н. Ничкало, А. Сманцера, О. Савченко, О. Сухомлинської та багато інших науковців. У працях із методики викладання педагогічних дисциплін А. Сиротенка, С. Коберника, В. Корнєєва, О. Плахотник, П. Шищенка, Б. Чернова, Л. Паламарчук, С. Розанова, О. Топузова та інших та досвіді вчителів-практиків Н. Муніч, Г. Карпюк, О. Швеця, Л. Кухар, О. Литвинчук, Н. Ягольник питання упровадження гуманістичного початку в навчанні розглядається з методичної точки зору.

Meта статmі. Гуманна спрямованість змісту освіти у вищий школі реалізується через комплексний розвиток особистості засобами педагогічних дисциплін, забезпечується системою педагогічних умов, з-поміж яких: створення ситуацій успіху в пізнавальній діяльності; реалізація диференційованого підходу до побудови змісту навчальної роботи учнів; організація групових форм пізнавальної діяльності на основі співтворчості та співпраці у системі «викладач - студент»; залучення учнів до участі в пізнавальних іграх, розроблені на основі актуального матеріалу.

Ідеї гуманізму було покладено в основу гуманістичної педагогіки - напряму сучасної теорії і практики виховання, який виник у 50-60 роках минулого сторіччя у 
США як педагогічне втілення ідей гуманістичної психології (А. Маслоу, К. Роджерс та інші). Головною метою гуманістичної педагогіки є самоактуалізація особистості. Водночас гуманістичні ідеї в Україні мають глибоке історичне коріння. Провідні науковці сьогодення I. Бех, I. Зязюн, М. Евтух, Т. Мацейков, Ю. Руденко, М. Стельмахович та інші вважають, що процес дослідження гуманізму можна розпочинати 3 вивчення традицій народної педагогіки України. Загальнолюдські цінності як основні критерії гуманізму - велике набуття народу. Вони дійшли до нас завдяки народній мудрості, народній моралі, пісням і думам, казкам і легендам, іграм і танцям, звичаям і традиціям, народному прикладному мистецтву. I наше сучасне тяжіння до чистих джерел народності великою мірою зумовлене саме дефіцитом гуманності, ностальгією за втраченими моральними цінностями. Поняття добра і зла, чесності і справедливості увібрала в себе народна педагогіка, що дійшла до нас у вигляді переказів, правил поведінки й ідей любові до ближнього [1, с. 69].

У загальному значенні «гуманізм» визначається як «історично змінювана система поглядів, що визнає цінність людини як особистості, іiі право на свободу, щастя, розвиток і прояв своїх здібностей, що вважає благо людини критерієм оцінки соціальних інститутів, а принципи рівності, справедливості, людяності - бажаною нормою стосунків між людьми» [3, с. 130].

Науковець І. Зязюн характеризує поняття гуманізму як «історично зумовлену систему поглядів, яка визнає людину самодостатньою цінністю, розглядає іiі як свідомий об'єкт своїх дій, розвиток якого за законами власної діяльності є необхідною умовою розвитку суспільства». Отже, в широкому розумінні під гуманізмом розуміють прагнення до людяності [2, с. 8].

Водночас оновлення вищої педагогічної освіти неможливо повноцінно здійснювати без урахування провідних тенденцій розвитку сучасної теорії і практики. Такими тенденціями $\epsilon$ : багаторівневість i багатоступінчатість; гнучкість i варіативність; відкритість і полікультурний характер, неперервність й урахування регіональних чинників. Нині виникли суперечності, властиві процесу підготовки педагогічних кадрів, 3-поміж яких найбільш значущими $\epsilon$ суперечності між абстрактним предметом навчально-пізнавальної діяльності у ВНЗ i реальним предметом професійно-педагогічної діяльності, де доводиться розв'язувати конкретні проблеми і віднайти вихід із ситуації, що склалася; між цілісністю змісту професійнопедагогічної підготовки і структуруванням змісту навчального курсу на різні предметні галузі без позначення взаємозв'язку між ними; між зверненістю змісту навчальної діяльності студентів до минулого досвіду й орієнтацією їх на майбутній зміст професійної діяльності, до невідомих ситуацій і умов педагогічної праці. Подолання цих суперечностей ми вбачаємо у проектуванні змісту вищої педагогічної освіти на основі переходу від «знаннєвої» парадигми підготовки спеціаліста до «індивідуально-творчої», яка передбачає всебічне використання в освітньому процесі особистісно орієнтованих технологій. Необхідно створити умови для того, щоб на всіх етапах професійної соціалізації студент виконував роль як суб'єкта самоорганізації вільного вибору професії і траєкторії своєї освіти, сценариста своєї професійної життєдіяльності. Як указують В. Матросов і В. Сластьонін, сучасна вища освіта переживає перехід від феноменологічних описів до побудови дійсно наукових теорій.

У результаті дослідження ми з'ясували, що система університетської освіти, орієнтована на фундаменталізацію наукової підготовки майбутніх спеціалістів, характеризується недостатнім рівнем психолого-педагогічного виховання, що негативно відображається на процесі адаптації студентів до обраної педагогічної 
спеціальності. За цих умов особливої актуальності набуває розроблення акмеологічного підходу, який грунтується на таких положеннях: а) 3 перших років навчання студента необхідно навчити співвідносити повний маршрут його навчання 3 кінцевими цілями навчання; б) необхідно ознайомити студента 3 його індивідуальними, особистісними і суб'єктивно-діяльнісними характеристиками порівняно з вищими рівнями професіоналізму; в) на основі такого зіставлення й усвідомлення свого потенціалу допомогти студенту виробити свій власний шлях досягнення майстерності у професійній діяльності, прогнозувати свій розвиток 3 урахуванням своїх індивідуальних та індивід них властивостей, визначити головну мету і цілі кожного етапу, шляхи, методи і технології досягнення вершин. Орієнтація на використання у процесі підготовки педагогічних кадрів різних категорій перспективної професіограми, спрямованої на «зону найближчого професійного розвитку», дозволить комплексно здійснювати підготовку спеціалістів освіти в системі класичних університетів.

Технології підготовки педагогічних кадрів в умовах університетської освіти, нам вбачається повинна будуватися з використанням таких перспективних підходів:

- Поглиблення змісту наявного психолого-педагогічного циклу дисциплін змістовим і доцільним з професійної точки зору навчально-виховним матеріалом. Цей напрям передбачає за необхідне доповнення навчальних програм і планів різними предметами загальнодидактичної і методичної спрямованості (О. Абдуліна, 3. Каргієва, Ю. Самарін, В. Сластьонін, В. Якунін та інші науковці).

- Реалізація у викладанні психолого-педагогічних курсів міжпредметних зв'язків. Цей напрям знайшов своє відображення у працях В. Гінецинського, Н. Кузьміної, В. Максимової, Г. Михалевської, А. Усової, В. Якуніна та ін. На початку педагогічної практики виникають труднощі, пов'язані з незадоволеністю психологопедагогічною і методичною підготовкою студентів до діяльності, відсутністю узгодженості й зацікавленості в роботі викладачів різних кафедр. Як показали праці дослідників, саме реалізація різних форм і методів реалізації міжпредметних зв'язків педагогіки 3 методиками викладання різних навчальних дисциплін $є$ дієвим засобом підвищення рівня професійно-методичної підготовки студентів до роботи у школі, а отже, і до формування у них чинників професійної стійкості.

- Покращення професійно-педагогічної підготовки студентів засобами спеціальних дисциплін. Цей напрям передбачає передавання студентам методичних знань, формування вмінь і навичок викладання певних предметів засобами власне навчального предмета. Питання впливу всієї системи навчально-виховної роботи у ВНЗ на формування особистості майбутнього вчителя неодноразово обговорювалися у психолого-педагогічній літературі (Ю. Азаров, 3. Каргієва, Н. Кузьміна, А. Щербаков та ін.). Випускники педагогічних навчальних закладів, як правило, у середній школі послуговуються методичними прийомами і способами роботи, які використовувалися викладачами вищої школи для їх підготовки, тобто намагаються вчити саме так, як їх учили у ВНЗ. Отже, всі види занять вже є джерелом знань 3 методики викладання, незалежно від того, чи ставлять викладачі перед собою такі завдання. Саме покращення професійно-педагогічної підготовки, а значить професійної стійкості студентів університету засобами спеціальних дисциплін містить невичерпні резерви удосконалення цієї підготовки, як за чинником часу, так і за цілями, формами й методами організації занять і спеціальних дисциплін.

Актуальною проблемою сучасної професійної освіти $є$ розв'язання завдання гуманізації дидактичного процесу у ВНЗ. Одним із перспективних шляхів іiі розв'язання може стати створення особистісно орієнтованих технологій навчання, у 
центрі уваги яких - унікальна цілісна особистість, яка прагне до максимальної реалізації своїх можливостей, відкрита для сприймання нового досвіду, здатна на усвідомлений i відповідальний вибір у різноманітних професійних ситуаціях. Технології особистісної орієнтації грунтуються на використанні методів і засобів навчання і виховання, відповідних індивідуальних особливостях кожного студента.

Донедавна більшість вітчизняних та зарубіжних дослідників розглядали цілісний педагогічний процес переважно як двобічну спільну діяльність вчителя й учня, де функції вчителя пов'язані із керівництвом педагогічним процесом, а учня - 3 репродуктивно-творчим оволодінням змістом навчання і предметом пізнання. У дослідженнях О. Дусавицького, В. Ляудіс, Н. Маслової, А. Мудрика, Г. Цукерман та інших навчальна діяльність є формою активного суб'єкт-об'єктного взаємозв'язку і становить сукупність дій, спрямованих на досягнення певної мети. Важливими характеристиками цілеспрямованої навчальної діяльності є наявність суб'єкта, об'єкта навчання, засобів і результатів діяльності.

Будучи складним структурним утворенням, діяльність у системі розвивального навчання охоплює такі блоки: мотиваційний, орієнтувальний, операційний, оцінний, енергетичний. Ми вважаємо, що особливе місце в системі навчально-пізнавальної діяльності при реалізації педагогічних ідей розвивального навчання займає комунікативний блок або спілкування, який виконує особливу роль у спільній, кооперованій діяльності. Зокрема, В. Ляудіс виокремлює такі важливі особливості спільної діяльності: співробітництво вчителя і учня; перебудову позиції особистості того, хто навчає, і того, хто вчиться, що виявляється у зміні ціннісних установок, смислових орієнтирів, цілей учіння і самого впливу в кожного з учасників навчання. Автор акцентує увагу не тільки на діловому, але й на особистісному спілкуванні у процесі спільної діяльності, виокремлюючи його як значущий канал становлення стосунків між учителем та учнями.

В аспектах організації розвивального навчання суттєвим $є$ те, що спілкування (особливо ділове, пов'язане з участю в спільній колективно-розподіленій діяльності) в умовах реалізації певних цілей у діяльності (педагога і учня), з одного боку, є засобом здійснення цієї діяльності. Педагогу важливо будувати навчальну діяльність за законами спілкування, спонукаючи учня до продуктивного співробітництва. Система розвивального навчання передбачає формування позиції дитини як повноцінного суб'єкта діяльності, на самостійно пройдених всіх іiі етапах: 1) цілепокладання; 2) планування; 3) реалізація мети; 4) аналіз (оцінка) результату.

На думку сучасних дослідників, розвивальне навчання здійснюється як цілеспрямована навчальна діяльність (ЦНД), у процесі якої дитина свідомо ставить навчально-пізнавальні цілі і завдання самозміни, а також творчо їх досягає. ЦНД - це діяльність, у якій дитина стає суб'єктом учіння, діяльність із самозміни. Організація ЦНД є головним, найбільш складним навчально-методичним завданням вчителя, яке розв'язується за допомогою різних методів і методичних прийомів, шляхом реалізації ідей і принципів проблемного навчання, постановки навчальних завдань, а також використання колективно-групових методів.

Педагогічні знання, одержані студентами на молодших курсах, $є$ засобами професійної адаптації, усвідомлення ними сутності й особливостей майбутньої професії. Вивчаючи теоретичні засади педагогічних дисциплін, майбутні вчителі осмислюють моральні основи професійної діяльності вчителя, соціальну значущість і відповідальність за іiі результати. Узагальнення й осмислення педагогічних знань відбувається на старших курсах, коли на основі одержаної системи психологопедагогічних знань, апробованих під час педагогічної практики, формуються основи 
педагогічного мислення й комунікативної культури, уміння творчо застосовувати знання у професійній діяльності.

У розрізі сучасних вимог до працівників освіти підвищення професійнопедагогічної культури педагогічних кадрів передбачає:

1) подолання ситуації, за якої сучасні педагогічні навчальні заклади готують учителів для школи вчорашнього дня; розроблення й експериментальна апробація кількох моделей усебічного реформування системи підготовки педагогічних кадрів iï організації, структури, принципів взаємозв'язку 3 освітньою практикою й інноваційними процесами в освіті; збільшення обсягу і підвищення якості підготовки педагогічних кадрів для системи початкової та середньої професійної освіти;

2) організацію i проведення всеобучу 3 інформаційних технологій для управлінських і педагогічних кадрів, з-поміж яких не більше чверті нині мають тільки ознайомлювальний рівень підготовки в галузі інформатики, а також створення необхідних умов у педагогічних навчальних закладах задля підготовки студентів майбутніх учителів до використання інформаційних технологій у професійній діяльності;

3) реорганізацію методичної служби органів управління освітою; побудову іiі діяльності на принципах мережевої організації і маркетингу поширення передових освітніх практик; створення розгалуженої інфраструктури методичних служб у формі творчих площадок, лабораторій передового досвіду, педагогічних майстерень на базі інноваційних освітніх установ і педагогічних практик;

4) реорганізацію й надання динамізму системі підвищення кваліфікації працівників освіти, реалізацію ідей неперервної професійної освіти; варто вже на студентській лаві готувати студентів до процесу неперервного професійного самовиховання, творчого зростання.

Ми вважаємо, що функціональний підхід до аналізу діяльності студентів майбутніх вчителів передбачає вироблення певного уявлення про структуру педагогічної праці і іiі інваріантних характеристик. Ми поділяємо відому позицію дослідників в галузі підготовки педагогічних кадрів у тому, що педагогічною професією можна оволодіти лише на індивідуально-творчому рівні. При цьому ми вважаємо за доцільне розглядати особистість учителя, а також майбутнього вчителя, як персоніфікацію нормативної діяльності, носія певних загальнолюдських цінностей, суб'єкта, здатного реалізувати в педагогічній професії свій спосіб життєдіяльності, готовність визначати педагогічні завдання і відповідати за їх розв'язання, виходити за межі нормативної діяльності.

Необхідність прогностичного моделювання особистості майбутнього вчителя спрямована не стільки на визначення інваріантних, ідеалізованих параметрів професійної діяльності педагога, скільки на виявлення різних чинників, які мають значний вплив на його особистісне і професійне становлення. Слід уважати, що головним критерієм моделювання діяльності вчителя $є$ професійна готовність до педагогічної діяльності, яка є інтегральним утворенням особистості і поєднує в собі мотиваційно-ціннісне ставлення до вчительської професії і володіння педагогічною діяльністю на операціональному рівні. При цьому цінності педагогічної діяльності, ставши особистісно значущими, виконують роль внутрішніх регуляторів суспільної і професійної поведінки вчителя.

Пов'язуючи свою долю 3 педагогічною діяльністю, необхідно кожному випускнику середньої школи адекватно оцінити міру своєї готовності до оволодіння основами педагогічної майстерності, рівень сформованості особистісних професійно значущих рис характеру, необхідних задля досягнення високого рівня в педагогічній 
діяльності.

Гуманізація процесу навчання якісно оновлює зміст освіти, тепер він є засобом розвитку внутрішнього світу майбутнього вчителя початкової ланки. Зміна освітніх ідеалів пов'язана з формуванням особистісних якостей особистості, наповненням його уявлень почуттями, ціннісними переживаннями і змістами. Гуманізація навчання акцентує увагу на необхідності розвитку у студентів самостійності, творчої ініціативи, потреби в самовдосконаленні, виявленні моральної позиції, естетичних поглядів тощо. Таке навчання робить студента творцем власної діяльності, що передбачає реалізацію його особистісних функцій у навчальному процесі, відповідальність за хід навчання. Подальшу роботу вбачаємо в розробленні індивідуальних проектів.

\section{Література}

1. Залуцький О. Гуманістичні засади в сучасному освітньо-виховному процесі / О. Залуцький // Рідна школа. - 2008. - № 1-2. - С. 69-70. 2. Зязюн І. А. Гуманістична стратегія теорії і практики навчального процесу / І. А.Зязюн // Рідна школа. - 2000. № 3. - С. 8-12. 3. Философский энциклопедический словарь / [гл. ред.: Л. Ф. Ильичёв, П. Н Федосеев, С. М. Ковалёв и др.]. - М. : Сов. энциклопедия, 1983. - 840 с.

УДК 37.013 .41

Кирило Пантелєєв

\section{ОСОБИСТІСНО ЗОРІЄНТОВАНЕ НАВЧАННЯ ЯК РЕСУРС ЗДОРОВ'ЯЗБЕРЕЖЕННЯ МАЙБУТНІХ ОФІЦЕРІВ-ПРИКОРДОННИКІВ}

Пантелєєв К. В. Особистісно зорієнтоване навчання як ресурс здоров'язбереження майбутніх офіцерів-прикордонників.

У статті розглядаються питання розвитку потреби і здатності особистості до саморозвитку у процесі навчання в контексті ідеї здоров'язбереження.

Ключові слова: особистість, розвиток, навчання, потреби і здатності, здоров'язбереження.

Пантелев К. В. Личностно-ориентированое обучение как ресурс здоровьесбережения будущих офицеров-пограничников.

В статье рассматриваются вопросы развития потребности и способности личности к саморазвитию в процессе обучения в контексте идеи здоровьесбережения.

Ключевые слова: личность, развитие, обучение, потребности и способности, здоровьесбережение.

Panteleev K. V. Personality-centered education as a resource of health protection of future border guard officers.

The article studies the issues with regard to developing person's needs and abilities for self-development in a training process in context of health protection.

Key words: personality, development, education, needs and abilities, health protection.

Однією 3 найважливіших проблем на тлі сучасних тенденцій розвитку суспільства $є$ збереження й зміцнення здоров'я особистості. У цьому контексті особливого значення набуває проблема організації здорового способу життя, формування культури здоров'я молодого покоління, адже здоров'я населення є одним із критеріїв розвитку будь-якої країни.

На важливості збереження й зміцнення здоров'я наголошено й у низці нормативних документів, зокрема в Законах України «Про освіту», «Про вищу 